\title{
The Threat of Shrinking Agency and Free Will Disillusionism
}

Thomas Nadelhoffer

Dickinson College

Word Count: 8,597 (w/out footnotes and bibliography)

The death of free will, or its exposure as a convenient illusion, some worry, could wreak havoc on our sense of moral and legal responsibility. According to those who believe that free will and determinism are incompatible...it would mean that people are no more responsible for their actions than asteroids or planets. Anything would go.

--Dennis Overbye, The New York Times (2007)

This is the excellent foppery of the world, that when we are sick in fortune, often the surfeits of our own behavior, we make guilty of our disasters the sun, the moon, and stars; as if we were villains on necessity; fools by heavenly compulsion; knaves, thieves, and treachers by spherical predominance; drunkards, liars, and adulterers by an enforced obedience of planetary influence; and all that we are evil in, by a divine thrusting on--an admirable evasion of whoremaster man, to lay his goatish disposition on the charge of a star.

--William Shakespeare, King Lear (1610/2005)

\section{Introduction}

During the past few years the popular press has become increasingly interested in free will, agency, and responsibility, with stories appearing in mainstream media outlets such as The New York Times, The Economist, Forbes Magazine, Wired, and FOX News. As psychologists continue to demystify the mind by uncovering the mechanisms that undergird human behavior, what was once an issue that fell mostly under the purview of philosophers and theologians has started to pique the curiosity of the public more generally. This interest is quite understandable. If free will provides the foundation for our traditional moral beliefs and practices, and its existence is incompatible with the gathering data from the so-called "sciences of the mind," then free will isn't just a topic fit for philosophers_-it is a psychological, sociological, cultural, and policy issue as well. To the extent that scientific advancements undermine or threaten our traditional views 
about human agency, we ought to carefully consider what impact this might have on our moral and legal practices.

In an attempt to address this issue, philosophers have recently begun thinking about what we ought to do in light of the gathering threats to human agency and responsibility. From Saul Smilansky's illusionism (2000; 2002) and Derk Pereboom's hard incompatibilism (2001) to Shaun Nichols' anti-revolutionism (2008), one finds several novel attempts to wrestle with what we should to in the face of the possible "death of free will”-to borrow a phrase recently used in The New York Times by Dennis Overbye. ${ }^{1}$ Given the timeliness, gravity, and complexity of the issues at stake, these philosophers are to be applauded for their efforts. However, I also believe that their respective views share one shortcoming - namely, each focuses primarily (if not exclusively) on the threat of determinism. In this respect, I share Eddy Nahmias' view that the focus on determinism that is often the hallmark of the free will debate can lead us to overlook more pressing threats to agency coming from psychology that are orthogonal to worries about the fundamental laws of the universe, the general nature of causality, and other related issues (Nahmias forthcoming).

Whereas the traditional free will debate focused on the free part of "free will"with an emphasis on alternative possibilities and the ability to do otherwise-many of the new threats from psychology pose potential problems for the will part as well. My primary goal in this paper is to shed some light on the nature of these potential psychological threats. In doing so, I first set the stage by explaining and clarifying some key terms and exploring some of the key issues from the free will debate (§1). Then, I examine several potential threats to free will that I am going to collectively call the

\footnotetext{
${ }^{1}$ A copy of the article can be found at: http://www.nytimes.com/2007/01/02/science/02free.html
} 
Threat of Shrinking Agency (§2). In piecing this general threat together, I discuss the work of several prominent psychologists including Jonathan Bargh, Benjamin Libet, Daniel Wegner, and others. My goal is not to argue that these threats actually do undermine free will and responsibility. Trying to accomplish this admittedly difficult task is beyond the scope of the present essay. Instead, my aim is simply to trace the boundaries of the potential threats that I examine and to show that they are not dependent on other potential threats such as determinism, mechanism, reductionism, and the like. Having canvassed some of the salient research from psychology, I will then end by briefly lobbying for philosophers to take a more active role in the paradigm shift that I believe is already under foot. On my view, rather than marshalling our forces together to stem the spread of skepticism as some philosophers have suggested (e.g., Smilansky 2000; 2002; Nichols forthcoming), I believe that we should instead be active agents of disillusionment and change when it comes to traditional views about human agency (§3).

\section{Setting the Stage}

The dominant issue in the free will debate has traditionally been whether free will and responsibility are compatible with determinism-i.e., the thesis that given the fixity of the past and the laws of nature, there is always only one possible future (Van Inwagen 1983). The attempt to address the compatibility question has spawned a litany of positions. ${ }^{2}$ Incompatibilists, for instance, run the gamut from pro-free will libertarians who suggest that we are unmoved movers (e.g., Chisholm 1982) to free will skeptics who claim that we can't be free and responsible regardless of the truth of determinism (e.g., Strawson 1986). A number of incompatibilists lie on a continuum between these two

\footnotetext{
${ }^{2}$ For a very helpful introduction to the major views in the free will debate, see Fischer et al. (2007).
} 
extremes. The two broadest pro-free will incompatibilist views are event-causal libertarianism (e.g., Ekstrom 2000; Kane 1996) and agent-causal libertarianism (e.g., Clarke 1996; 2003; O’Connor 1993; 2000)_each of which maintains that determinism is false and that human beings are (sometimes) free and morally responsible. Non-realism about free will and moral responsibility, on the other hand, comes in several stripes as well (e.g., Double 1991; Honderich 1998; Smilansky 2000; 2002; Pereboom 2001; Sommers 2007; Strawson 1986)_-some of which are driven by worries about determinism and some of which are not.

Predictably, there are just as many varieties of compatibilism. Compatibilists known as soft determinists, for instance, claim that free will and responsibility actually require determinism (e.g., Ayer 1982; Stace 1952). Most compatibilists, however, are merely committed to the weaker conditional view that we could be free even if determinism were true. ${ }^{3}$ Of course, even this is an issue about which compatibilists disagree. Semi-compatibilists, for instance, think that while determinism may very well preclude free will, it is does not undermine moral responsibility (e.g., Fischer 1994; 2007; Fischer \& Ravizza 1998). On this view, the latter does not require us to have alternative possibilities. Instead, moral responsibility merely requires us to have the capacity for understanding and acting (or not) upon moral reasons. If this were correct, free will would not be a necessary condition for responsibility — which is something most compatibilists would deny. But despite their differences, semi-compatibilists and compatibilists agree that we could be morally responsible even if determinism is true.

\footnotetext{
${ }^{3}$ For recent overviews of the several faces of contemporary compatibilism, see Berofsky (2002); Haji (2002); Mele (2007); and Russell (2002).
} 
Given that the free will literature is a vast and tangled web, a few more clarifications are in order before we examine the data from psychology. ${ }^{4}$ First, when talking about the kind of free will that is at stake between the fighting factions within the incompatibilist camp, I will use either the term libertarian free will or simply free will. Libertarians claim that we have it. Free will skeptics claim that we don't. Second, when talking about the kind of free will that is usually in the offing by the compatibilist camp, I will use a cluster of related terms such as compatibilist control, self-regulation, and practical deliberation. However, since I believe calling this kind of control "free will" unnecessarily muddies the dialectical waters, I will break with both compatibilists and revisionists and refrain from doing so here. On my view, if we do not have libertarian free will, we do not have free will at all.

My main reason for limiting the application of the term "free will” to the kind of metaphysically spooky stuff that immaterial souls are made of is that I do not believe that the kinds of cognitive capacities that compatibilists try to reconcile with determinism adequately capture the full spectrum of folk intuitions about free will. But that is an admittedly messy empirical question that has recently received a fair amount of attention. ${ }^{5}$ As it stands, however, the verdict is still out. So, for now, I am simply going to assume for the sake of argument that the common sense notion of free will is loosely libertarian and that we don't have it. Adequately defending either of these assumptions is beyond the scope of this essay. For present purposes, the important point is that even

\footnotetext{
${ }^{4}$ There are several other major views in the free will literature that do not fit into either the incompatibilist or the compatibilist camps but that I will not have time to discuss here. Examples include Saul Smilansky's fundamental dualism (2000; 2002), Al Mele's agnostic autonomism (2001), and Manuel Vargas' revisionism (2005; 2007) - to name just a few.

${ }^{5}$ See, e.g., Nadelhoffer \& Feltz (2007); Nahmias et al. (2005); (2006); Nahmias (2006); Nichols \& Knobe (2007); and Woolfolk et al. (2006).
} 
though I do not believe that we have free will in the traditional sense, I still believe that we could have the capacity for self-control and practical reason even if determinism were true. Moreover, I believe that these kinds of cognitive capacities are enough to ground some pared down kind of responsibility — which brings us to our next important distinction.

When talking about responsibility in this paper, I will always try to make it clear whether I am talking about desert-based responsibility or consequentialist-based responsibility. Moreover, I will focus primarily on the kind of responsibility that underpins punishment since it helps illuminate the key difference between saying that someone is answerable in some minimal way for violating a norm and saying someone morally deserves to suffer for violating a norm. On my view, to say that an agent is desert-based responsible for breaking some moral or legal norm $x$ is to say that she deserves to suffer for $x$-ing even if the suffering produces no other tangible benefits. ${ }^{6}$ To say that an agent is consequentialist-based responsible for $x$-ing, on the other hand, is to say that she ought to suffer only if the suffering would decrease the likelihood that she (and others) will $x$ in the future. The main difference between the two is that whereas the former maintains that making agents suffer for knowingly violating moral and legal norms is intrinsically valuable, the latter places merely instrumental value on the suffering. So, for instance, if there were two equally effective penalties available for a particular norm violation in terms of deterrence-one of which involves suffering and the other of which does not-the proponent of a desert-based approach must opt for the former while the proponent of a consequentialist approach must opt for the latter.

\footnotetext{
${ }^{6}$ For ease of exposition, I will focus on bad actions and blameworthy agents in this paper, but the same notion of moral desert applies to good acts and praiseworthy agents as well.
} 
By my lights, when examining what's at stake in the free will debate, we must resist the temptation to conflate these two kinds of responsibility. After all, one could be an incompatibilist about determinism and moral desert but a compatibilist with respect to determinism and consequentialist-based responsibility—which is essentially the kind of view that I hold. Unfortunately, people are not always sufficiently careful when it comes to maintaining a clear line between these twin faces of responsibility. Keep in mind that one of the key issues in the debate between libertarians and free will skeptics is moral desert. Are human beings the kinds of creatures who deserve to suffer for their wrongdoings even if the suffering is otherwise non-compensatory? Libertarians and skeptics both agree that if humans are to be morally responsible in the robust desert-based sense, we would need to have libertarian free will. The two camps simply disagree about whether we actually have it.

Compatibilists, on the other hand, are not always clear on this point. One can find them sliding back and forth between desert-based and prevention-based responsibility—a move that is facilitated by the fact that we can use the same general term to refer to both. Consider, for instance, the following pair of remarks by Daniel Dennett:

1. Is she [i.e., the free will skeptic] going to jettison our system of law and punishment? Is she going to abandon the social leverage by which we encourage people to take responsibility for their actions? Is she prepared to dismiss the distinction between honesty and cheating as just another myth fostered by the traditional concept of free will? (2008: 255)

2. We ought to admit, up front, that one of our strongest unspoken motivations for upholding something close to the traditional concept of free will is our desire to see the world's villains get what they deserve. And surely they do deserve our condemnation, our criticism, and - when we have a sound system of laws in place-punishment. (2008: 258) 
The way Dennett frames the debate here between the realists and non-realists about free will is misleading since he makes it seem as if skeptics are denying that we should have systems of social and legal norms. But the skeptic does not need to reject the importance of norms any more than she needs to reject the distinction between honesty and deceit. Instead, she merely denies that people who lie deserve to suffer for doing so. This is not to suggest that we don't need sanctions in place to deter people from lying-it’s just to say that the point of the sanctions is forward rather than backward looking.

Perhaps Dennett presents free will skeptics in an unduly implausible light because he has conflated the rejection of moral desert with the rejection of any mechanisms of accountability whatsoever. If so, this is a mistake. For even though I happen to believe that determinism precludes both free will and moral desert, I am nevertheless able to consistently maintain that social stability requires a system of social and legal norms, that practical deliberation and self-control are two key elements of responsible agency, and that these two cognitive capacities are compatible with determinism. Given that one can be both a compatibilist (of sorts) and an incompatibilist (of sorts) in this way, we must maintain a bright line between the different kinds of responsibility when arguing about free will.

Another undesirable side effect of failing to adequately distinguish desert-based from consequentialist-based responsibility is that it misleadingly makes it look like there is a deep rift between compatibilists and free will skeptics when in many cases I would argue that the disagreement between the two camps is mainly terminological. After all, both camps typically agree about several key issues. First, each camp believes that we do not have libertarian free will. Second, each camp nevertheless believes that we have a 
bounded capacity for self-regulation and rational deliberation. Finally, compatibilists and free will skeptics also agree that there are important practical considerations that necessitate that we have a formalized system for holding people accountable for breaking social and legal norms. Given these similarities, the two main issues that distinguish compatibilists from free will skeptics are (a) whether we should call compatibilist control "free will," and (b) whether compatibilist control is enough to ground moral desert. Resolving this last issue is only possible if we avoid conflating desert-based and consequentialist-based responsibility.

The most obvious solution would be to limit the term "moral" to desert-based responsibility. We could then call the other kind of responsibility something else-e.g., answerability, accountability, etc. ${ }^{7}$ This move is in line with my earlier insistence that we limit our application of the term "free will" to instances of libertarian free will. My goal in each of these cases is not to be unduly contrarian. Nor am I engaging in mere semantic quibbling. Rather, I think that what we call things matters. And I also think the terms "free will" and "moral responsibility" carry an awful lot of both metaphysical and historical baggage. From the story about free will's role in our purported fall from grace in the Garden of Eden to the Cartesian dualism that aimed to make room for free will in an otherwise mechanistic universe, in the Western tradition the notion of free will has often been aligned with that which is supernatural within us - that ephemeral ghost that so curiously haunts our lowly bodily machine. Moreover, it has historically been conceptualized as that part of us that separates us from "the beasts," makes us morally responsible for our behavior, and determines whether we end up with eternal damnation

\footnotetext{
${ }^{7}$ Gary Watson helpfully distinguishes between what he calls accountability and attributability (2004: 260288).
} 
(or salvation). Given this web of historical associations I do not think that we should revise the terms "free will" and "moral responsibility." If we don't have the kind of agency and responsibility that people have traditionally thought we had, we invite confusion by continuing to use the old terms to talk about what we actually do haveespecially when we could simply use other terms which are less loaded.

Another frustration that has always lurked in the background of the free will debate is that it is unclear what kind of evidence could possibly establish whether universal determinism is true. As it stands, the scientific consensus is that causality is indeterministic at the quantum level. Whether this quantum indeterminacy "bubble ups" in a way that would help libertarians such as Robert Kane (1996) is entirely unclear. Consequently, a number of incompatibilists will continue to remain hostage to future developments in quantum physics. Compatibilists, on the other hand, often reject this kind of waiting game outright. John Martin Fischer, for instance, recently claimed that, "our most fundamental views of ourselves as free and responsible should not, as it were, 'hang on a thread'—should not depend on subtle and arcane deliverances of theoretical physicists” (Fischer 2007: 71). Regardless of whether one shares Fischer's deflationary attitude towards the threat of determinism, it is clear that philosophers will remain at an argumentative impasse until we know more about the fabric of the universe.

In the meantime, I think philosophers and psychologists should focus on other threats that are both more pressing and more challenging than the specter of determinism. The issue is not whether the mind is deterministic or mechanistic-the scientific consensus seems to be that it is both (see, e.g., Walter 2001: 162)—but rather whether the conscious mind plays the central etiological role that we have traditionally assumed. For 
instance, if our conscious mental states are merely epiphenomenon as some psychologists have suggested (e.g., Wegner 2002), then regardless of the truth of determinism it wouldn't make sense to say that we are free. At the end of the day, indeterministic epiphenomenalism is no less worrisome than deterministic epiphenomenalism. Either way, there wouldn't be room for libertarian free will because there wouldn't be room for conscious will at all. Only the buzzing and whirling of the unconscious would have any real etiological role to play.

In light of this kind of worry, Nahmias has recently identified himself as a "neurotic compatibilist" (forthcoming)—i.e., someone who thinks free will and responsibility are compatible with determinism but who nevertheless worries that developments in psychology could pose an independent threat. There are at least two important components to his view. First, he is worried that future developments in psychology could be incompatible with both libertarian free will and compatibilist control (hence, the neurotic part). Second, Nahmias nevertheless believes that determinism per se is compatible with free will and moral desert (hence, the compatibilist part). So, while he is confident that determinism does not pose a threat, he is nervous that perhaps future developments in psychology could. I, on the other hand, am outright skeptical about the existence of free will and moral desert on both fronts.

First, when it comes to the traditional compatibilism debate, I believe that libertarian free will is what is needed to undergird moral desert, and that libertarian free will is incompatible with the truth of determinism. That makes me an incompatibilist in the traditional sense. At the same time, I also believe that self-control and practical reason are compatible with determinism, and these capacities are enough for 
consequentialist-based responsibility even if they are not enough for moral desert. In this respect, I am also a compatibilist of sorts. However, regardless of whether these selfregulative capacities are compatible with determinism, they could be incompatible with a number of other things (e.g., manipulation, mental illness, automaticity, epiphenomenalism, etc.). These "other things" are the ultimate source of Nahmias' aforementioned unease—and for good reason.

On my view, the gathering data from psychology that we will examine in the following section are inconsistent with our traditional view of ourselves as fully free and autonomous moral agents. So, on this front, I am actually pessimistic when it comes to the fate of free will rather than merely anxious or neurotic. However, while Nahmias and I admittedly disagree when it comes to how concerned we presently ought to be, we nevertheless share a common methodological starting point. On both of our views, the old compatibility question is less interesting and less pressing than the potential threats posed by the literature on the automaticity of the mind, situationism, introspection, and epiphenomenalism. As such, we both advocate that philosophers focus more of their attention on what could helpfully be called the New Compatibility Problem—a problem that has often been obscured by orthogonal worries about determinism, mechanism, physicalism, and reductionism. That being said, it is finally time to turn our attention to the collective threat from psychology that is the focus of the present paper.

\section{The Threat of Shrinking Agency}

The first thing worth pointing out about what I am calling the threat of shrinking agency is that it is driven by developments in several different areas of psychology. While it is 
doubtful that any particular data set or research program could sound the death knell of free will and desert-based responsibility, I nevertheless think that the literature examined in the following pages collectively shifts the burden to those who maintain that our traditional conceptions of human agency are compatible with the picture of the mind that is being pieced together by psychologists. But I am getting ahead of myself. There will be time for shifting burdens down the road. For now, one more preliminary distinction needs to be made.

As we will see in the following pages, there is an important difference between partial agential threats and global agential threats. A partial agential threat is one that merely constrains or shrinks the domain of our conscious agency and control. A global agential threat, on the other hand, is one that does not leave any room for conscious volition at all. Examples of the former can be found in the literature on automaticity (e.g., Bargh) while examples of the later can be found in the literature on epiphenomenalism (e.g., Wegner). It is also worth pointing out that the partial and global agential threats we are going to examine have nothing to do with whether (a) the laws of the universe are deterministic, (b) the conscious mind can be reduced to underlying mechanisms in the brain, (c) all mental events are caused by prior physical events, or (d) all mental events supervene on physical events. Instead, the agential threats that we will be examining here are ultimately fueled by the fact that the conscious mind exercises less control over our behavior than we have traditionally assumed. It is this deflationary view of conscious volition that is potentially agency undermining. After all, the less conscious 
willing we are able to do, the less free will we are able to have-which is true independently of traditional threats to free will such as determinism. ${ }^{8}$

Consider, for instance, the fascinating work by Bargh on the role of the unconscious mind. On his view, the data on automaticity indicate that "most of our dayto-day actions, motivations, judgments, and emotions are not the products of conscious choice and guidance, but must be driven instead by mental processes put into operation directly by environmental features and events” (Bargh and Chartrand 1999: 465). According to Bargh, it's not that conscious mental states don't have any volitional role to play. Rather, it's just that this role is markedly more circumscribed than we previously thought. In light of the gathering evidence, Bargh predicts that:

[T] the less need we have for postulating internal conscious mediating process to explain these phenomena....[I]t is hard to escape the forecast that as knowledge progresses regarding psychological phenomena, there will be less of a role played by free will or conscious choice in accounting for them....That trend has already begun..., and it can do nothing but continue. (Bargh 1997: 1)

In attempting to understand Bargh's pessimistic stance towards the fate of free will, it would be instructive for us to examine some of what I take to be the more interesting and important priming studies. The first involved exposing participants to words that were related either to being polite (e.g., considerate, respect, polite) or to being rude (e.g., impolite, obnoxious, rude) (Bargh \& Chartrand 1999). In each condition, the primed terms were interspersed with a number of other random words for the purposes of the experiment. The participants were told that once they were done reading through the list, they were to ask the experimenter for directions for the second step of the experiment. At this point, they would each find the experimenter speaking with a confederate in the hall.

\footnotetext{
${ }^{8}$ This is not to say that these other things don't pose a threat-it's just to say that to the extent they pose a threat, they do so independently of the psychological threats that are the topic of the present paper.
} 
This set up the crux of the study which was to determine whether those who were primed with polite words would be more patient and polite than those primed instead with rude words. Whereas the majority of the participants in the "rude" condition interrupted (67\%), far fewer participants interrupted in the other two conditions (38\% in the control condition and $16 \%$ in the "polite" condition).

In another one of Bargh's studies, participants were primed (or not) with an achievement goal (Bargh \& Chartrand 1999). They were then asked to identify and write down as many words as they could, based on a set of seven "Scrabble" letter tiles. A few minutes later, they were told over an intercom to stop. Hidden video cameras recorded the participants' behavior throughout to see how many of them continued to search for and write down words after they were told to stop doing so. Whereas only $21 \%$ of the participants in the control condition cheated, more than half of the participants in the "achievement" condition (55\%) ignored the instructions to stop.

Finally, in a similar study run by Guido Hertel and Norbert Kerr (2000), participants were exposed either to terms such as fair, impartial, prejudiced, and favoritism (in the equality condition) or to terms such as trustworthy, betrayal, and disloyal (in the loyalty condition). Having been individually exposed to one of these two sets of words, participants were then brought together to take part in a minimal group paradigm experiment. Hertel and Kerr found at least two interesting and important results. First, participants in the "loyalty" condition showed greater in-group favoritism with respect to resource allocation and they exhibited a stronger identification with their in-group than the participants in the "equality" condition. Second, participants in the "loyalty" condition also experienced higher self-esteem the more group favoritism they 
showed. Participants in the "equality" condition, on the other hand, experienced lower self-esteem the more favoritism they showed.

By my lights, the existing data on priming and automaticity collectively establish that morally insignificant situational cues and stimuli both can and do have a significant effect on our moral behavior. ${ }^{9}$ Moreover, it appears that our conscious minds are often blind to the forces that drive our behavior-even when these forces are ones that we would neither endorse nor identify with if asked to do so. For instance, other studies have shown that our moral behavior is sensitive to contextual variables such (a) the level of ambient noise in our immediate environment (Mathews \& Cannon 1975), (b) how many people happen to be standing around at the time (Latane \& Darley 1970), (c) whether the person telling us to do something morally suspect happens to be wearing a lab coat (Milgram 1974), (d) whether or not we find a dime on a public telephone (Isen \& Levin 1972), (e) whether or not we are in a hurry (Darley \& Batson 1973), and (f) whether or not we have recently been primed to think about a ghost (Bering et al. 2005). ${ }^{10}$ In each case, one finds morally extraneous situational variables having a stark effect on people's moral behavior without their awareness-an effect they often understandably deny when pressed.

If nothing else, the literature on automaticity puts pressure on what Bargh aptly calls the assumption of "conscious primacy"-i.e., the view according to which most of our overt behavior is ultimately driven by high level conscious mental states. Indeed,

\footnotetext{
${ }^{9}$ For criticisms of the automaticity literature, see Kihlstrom (2008); Logan (1997); and Pashler (1998).

10 Both John Doris (1998; 2002) and Gilbert Harman (1999; 2000) have relied upon the data on automaticity and situationism to criticize the empirical credibility of virtue ethics. On their view, virtue ethics does not comport with what researchers are discovering about the nature of moral cognition and social behavior. For responses on the part of virtue ethics, see Kamtekar (2004); Miller (2003); Sabini and Silver (2005); and Solomon (2003).
} 
Bargh suggests that the only reason we find the literature on automaticity and situationism so surprising is that we view it against the backdrop of the assumption of conscious primacy. Yet, as intuitive as this assumption happens to be, Bargh claims that it flies in the face of the gathering data. On his view, the unconscious mind is "the rule in nature, not the exception” (2008:149). So, while it is true that our subjective phenomenology "has given us the strong sense, difficult to overcome, that our ethereal free will is the source of our behaviors, judgments, and goal pursuits” (2008: 146-147), we no longer need to appeal to the conscious will to explain even some of our most complex actions.

One obvious response to the automaticity literature is to optimistically fall back on introspection in an effort to stave off the situationist threats to our moral agency. Unfortunately, as tempting as this response might appear at first blush, introspection isn’t likely up to the task. For instance, in a series of papers in the late 1970's, Richard Nisbett and Timothy Wilson provided evidence that "there may be little to no direct introspective access to higher order cognitive processes” (1977: 231). On their view:

Subjects are sometimes (a) unaware of the existence of a stimulus that importantly influenced the response, (b) unaware of the existence of the response, and (c) unaware that the stimulus has affected the response. It is proposed that when people attempt to report on their cognitive processes, that is, on the processes mediating the effects of a stimulus on a response, they do not do so on the basis of any true introspection. Instead, their reports are based on a priori, implicit theories or judgments about the extent to which a particular stimulus is a plausible cause of a given response. (Nisbett \& Wilson 1977: 231)

Given these limitations, introspection is unlikely to enable us to fully escape the clutches of automaticity and situationism. The less conscious access we have to the root causes of our behavior, the less conscious control we have over how our lives unfold-which will be a recurring theme in the pages ahead. 
At this point, we can draw two conclusions. First, our moral behavior can be both initiated and driven by processes that lie beneath the veil of consciousness (e.g., Bargh). Second, introspection is unlikely to give us reliable access to the ultimate causes of our own complex behavior (e.g., Nisbett \& Wilson). In short, our conscious minds play a less prominent role in how our lives unfold than we previously assumed. Moreover, the role it does play seems to be quite fragile. For present purposes, I am going to call this collective threat to autonomy the Rarity Thesis. And while this view admittedly leaves room for conscious agency, it does not leave nearly as much as most libertarians and compatibilists would presumably prefer. Minimally, I think the rarity thesis can be used to motivate a deflationary view of agency and moral responsibility. Fleshing out what this pared down view might look like would take us too far afield. For now, I want to turn our attention instead to two more radical threats to free will that are already lurking in our midst - the first of which is based upon the ground-breaking work of Benjamin Libet.

In Libet (1999), for instance, participants were trained to focus their attention on the "first awareness of a wish or urge to act" (Libet 1999: 49). ${ }^{11}$ Once they had grown accustomed to identifying the onset of their conscious urges, they were asked to perform a simple flick of the wrist whenever they felt the urge to do so (in 30 second increments). Information about the participants' respective readiness potentials-i.e., the slow electrical charges that have been shown to precede "self-paced" voluntary actions-were recorded via readings of their scalps. As Libet correctly points out, "in the traditional view of conscious will and free will, one would expect conscious will to appear before, or at the onset, of the RP, and this command the brain to perform the intended act” (Libet

\footnotetext{
${ }^{11}$ See, also, Libet (1985); (2001); (2004); and Libet et al. (1983).
} 
1999: 49). However, this is not what appeared to happen at all. According to Libet's interpretation of the data, the brain processes that prepared the participants for their voluntary actions preceded conscious awareness by 400 msecs. (Libet 1999: 51) In short, Libet claims that his participants' brains were forming decisions or intentions prior to conscious awareness. ${ }^{12}$

A series of recent studies by John-Dylan Haynes and colleagues produced similarly surprising results. In one study, participants could freely choose to press a button with either their left hand or their right hand (Soon et al. 2008). Their task was to remember the precise time at which they consciously settled on a choice. The researchers were able to use brain signals from the participants to predict their choice up to seven seconds before they consciously made their decision. Using highly sophisticated computer programs and advanced imaging techniques, Haynes and colleagues used micro-patterns of activity in participants' frontopolar cortexes to predict their choices up to seven seconds before they became consciously aware of which button they were going to push.

In light of these results, it might be tempting to conclude that conscious mental states don't have any etiological role to play at all. But, as Libet is quick to point out, even in his own studies conscious awareness appears approximately 150 msec. before muscle activation. So, even though conscious awareness appears after the onset of RP, it could nevertheless affect the output of volitional processes. In light of this possibility,

\footnotetext{
${ }^{12}$ Libet has been widely, and I believe correctly, criticized on this point. One particularly exacting criticism has been developed by Al Mele (see, e.g., Mele 2004; 2006; 2008a; 2008b). On his view, a rival interpretation of the data that he calls the "urge hypothesis" not only does a better job of explaining Libet's results, but it also leaves room for the traditional view of conscious agency. For other critical responses to Libet's work see Bayne (2006); Gallagher (2006); Pacherie (2006); Pockett et al. (2006); Ross (2006); and Zhu (2003).
} 
Libet claims that our conscious will may have a kind of veto-power over the actions that our bodies antecedently prepare us to perform. On this view-which I am going to call the Gatekeeper Thesis - the "conscious will might block or veto the process, so that no act occurs” (Libet 1999: 52). ${ }^{13}$ As Libet claims:

The role of conscious free will would be, then, not to initiate voluntary action, but rather to control whether the act takes place. We may view the unconscious initiatives for voluntary actions as 'bubbling up' in the brain. The conscious will then selects which of these initiatives may go forward to an action or which ones to veto and abort, with no act of appearing. (1999: 52)

But if the conscious mind merely serves as a sentinel—allowing some unconscious action plans to come to fruition while blocking others-then it is unclear to me how we could have free will. At best, it appears that Libet provides us with what others have called free won’t (Ohbi \& Haggard 2004).

For now, I want to set aside the question of whether the gatekeeper thesis is true. Instead, I simply want to emphasize that the potential threat that Libet's veto power poses to our traditional conception of agency is entirely independent of the issue of determinism—which is something Libet himself seemingly fails to realize. Consider, for instance, his claim that the view that we are "genuinely free in the non-determined sense," is "at least as good, if not better, scientific option than is its denial by determinist theory" (1999: 56). These remarks suggest that Libet has misunderstood the novel threat posed by his studies. The worry isn’t (a) whether the laws of nature are deterministic, (b) whether our minds are mechanistic, or (c) whether our conscious mental states are determined by prior unconscious mental states. After all, the gatekeeper thesis-like the aforementioned rarity thesis - is neutral with respect to these traditional threats to free will.

${ }^{13}$ Baumeister (2008) develops a similar non-volitional notion of conscious control. 
The real worry raised by Libet's data is that our conscious mental states do not appear to play the etiological role we have traditionally assumed. Moreover, when our capacity for inhibition and practical deliberation is as flimsy as Roy Baumeister's work on ego-depletion suggests, we have all the more reason to be concerned (see, e.g., Baumeister 2008). For not only is my conscious self not the volitional source of my behavior, but my limited capacity to control my unconsciously initiated urges, intentions, and plans is sensitive to many factors about which I am unaware and over which I do not have control. By my lights, the more circumscribed our conscious minds become, the less room there will be for libertarian free will and desert-based responsibility. That being said, it is worth pointing out that the gatekeeper thesis is nevertheless consistent with some deflationary notions of conscious agency. For while it may turn out that the conscious mind is regulative rather than volitional, it could still play an important role in how our lives unfold.

If, on the other hand, we don't at least have the kind of minimal control that one finds in Libet's veto power, then epiphenomenalism would be the only remaining possibility. According to Libet, if this were the case, it would undermine our moral agency altogether:

In such a view, the individual would not consciously control his actions; he would only become aware of an unconsciously initiated choice. He would have no direct conscious control over the nature of the preceding unconscious processes. But a free will process implies one could be held consciously responsible for one's choice to act or not to act. We do not hold people responsible for actions performed unconsciously, without the possibility of conscious control. (Libet 1999: 52) 
Given the deep entrenchment of our moral reactive attitudes and our belief in the causal efficacy of the conscious mind, Libet thinks the burden is on those who would deny the existence of conscious agency.

Daniel Wegner is one psychologist who takes up the challenge. ${ }^{14}$ On his view, the traditional picture of the conscious will is not easily reconciled with the complex picture of the mind that is slowly being pieced together by psychologists. As he says:

The mechanisms underlying the experience of will are themselves a fundamental topic of scientific study. We should be able to examine and understand what creates the experience of will and what makes it go away. This means, though, that conscious will is an illusion. It is an illusion in the sense that the experience of consciously willing something is not a direct indication that the conscious thought has caused an action. Conscious will, viewed in this way, may be an extraordinary illusion indeed. (Wegner 2003: 2-3)

According to Wegner, while it is important to better understand why we think the conscious mind is volitional, at the end of the day our self-conception on this front is illusory. Unfortunately, Wegner's account of the illusory nature of our views about mental causation is a bit vague. While he sometimes appears to be arguing for the kind of epiphenomenalism one finds in the literature on the philosophy of mind-i.e., the view that conscious mental states are entirely causally inert—at other times it seems as if he has something else in mind. If conscious mental states were wholly causally inefficacious, then it wouldn't make sense to say that they do anything positive for us or that they help us in any way. However, Wegner suggests that these conscious states do play a role in how our lives unfold, just not the role we previously thought. ${ }^{15}$

\footnotetext{
${ }^{14}$ For other work on apparent mental-causation, see Brown (1989); Claxton (1999); Michotte (1963); Spence (1996); and Thompson et al. (1998).

${ }^{15}$ Wegner draws a curious analogy between the role played by our conscious mental states and the role played by a compass. Just as the later guides us without causing us to go one way or the other, so the conscious self purportedly shapes our behavior by helping us distinguish the things we do from the things we don't do. See, e.g., Wegner (2003, Cha. 9).
} 
Nahmias has suggested that perhaps the best way to interpret Wegner on this front is to assume that he is developing modular epiphenomenalism. On this view, "it is not that conscious mental states in general are epiphenomenal but that specifically those thoughts and intentions we experience just before actions as the cause of those actions do not in fact cause our actions" (Nahmias 2002: 530). This interpretation fits quite nicely with several things Wegner says when explicating his view. Consider, for instance, the following two comments:

1. Still the automatisms and illusions of control that lie of this diagonal remind us that action and the feeling of doing are not locked together inevitably. They come apart often enough to make us wonder whether they may be produced by separate systems in the mind. The processes of mind that produce the experience of will may be quite distinct from the processes of the mind that produce the action itself. As soon as we accept the idea that the will should be understood as an experience of the person who acts, we realize that conscious will is not inherent in action-there are actions that have it and actions that don't. (Wegner 2003: 11)

2. Perceiving mind and causal agency [via intentions, beliefs, desires, and plans] is a significant human ability. It is possible that this achievement is accomplished by a fairly narrow mental module, a special skill unit of mind that does not only this, and that in different individuals this module can thus be particularly healthy, damaged, or even non-functional. (Wegner 2003: 24)

In supporting his view, Wegner appeals to studies which show that participants' experience of control over an action can be severed from their actual performance (or non-performance) of the action. On the one hand, we sometimes find what appear to be otherwise purposive behavior which participants nevertheless perceive to be foreign to or outside their conscious control (e.g., hypnosis and alien hand syndrome). On the other hand, we find agents who think they are exercising control when they are not (e.g., positive illusions of control). According to Wegner, these kinds of studies highlight the fact that our experience of conscious will cannot, in and of itself, be taken as evidence 
that our conscious will is the ultimate source of our actions. After all, if feelings of will (or lack thereof) can be entirely decoupled from purposive behavior, then we can't assume that just because we experience the former that we are the ultimate cause of the latter. In short, while we often consciously experience an "internal oomph" when performing actions that we take to be voluntary and intentional, there is no guarantee that this experience is veridical.

According to Wegner, while the experience of will misleads us into believing in the "magic of our own causal agency," the actual causal springs of our behavior dwell below the veil of consciousness (2003: 28). On this view:

The mind is a system that produces appearance for its owner...The mind creates this continuous illusion; it really doesn't know what causes its own actions. Whatever empirical will there is rumbling along in the engine room-an actual relation between thought and action-might in fact be totally inscrutable to the driver of the machine (the mind). The mind has a self-explanation mechanism that produces a roughly continuous sense that what is in consciousness is the cause of action - the phenomenal will — whereas in fact the mind can't ever know itself well enough to be able to say what the causes of its actions are. (Wegner 2003: 28)

If Wegner were right that our conscious minds don't have access to the actual causes of our behavior, it is unclear how we could be said to behave freely and responsibly. As we saw earlier when we examined the gatekeeper thesis, free will and desert-based responsibility require that our conscious mental states are volitional. In this respect, both Libet's veto power and Wegner's illusion of conscious will threaten our traditional conception of human agency. However, Wegner's view is potentially much more corrosive.

Keep in mind that while Libet's veto power may not be enough for libertarian free will and desert-based responsibility, it is nevertheless enough for compatibilist control, 
self-regulation, etc. Wegner's view, on the other hand, does not appear to leave room for our conscious mental states to play any real etiological role at all. So, whereas Libet's view merely shrinks the domain over which we exercise control, Wegner seemingly leaves the conscious mind out of the causal loop altogether. After all, if the unconscious mind is the captain of our proverbial ship—with conscious mental states merely serving the lowly role of compass as Wegner suggests—-then the unfolding of our lives ultimately depends on the former and not the latter. For it is the captain, not the compass, who decides where the ship is going in the first place.

As such, Wegner's view—which I am going to call the Bypassing Thesisrepresents a global and not merely partial agential threat. By my lights, if the bypassing thesis were correct, then our conscious minds would simply be along for the ride, etiologically speaking. This would have far reaching implications as far as free will is concerned. Not only would we not have libertarian free will, but we wouldn't even have the kind of conscious control that compatibilists have tried to use to ground moral desert. In the face of the bypassing thesis, what's left of moral responsibility—if anything is left at all—is little more than moral luck. By leaving "us" out of the story about agency and action, it removes us from the sphere of moral desert altogether. Only my body and brain—neither of which I can directly control—are left to "blame" for our behavior. And if you, like me, don’t think it makes sense to say that people deserve blame (or praise) for things over which they have no ultimate control, then epiphenomenalism represents the greatest threat of all to free will and desert-based responsibility. At the end of the day, Wegner's bypassing thesis threatens to leave us adrift on a sea of unconscious forces that we are powerless to change. So, while I am presently unpersuaded by Wegner's attempts 
to empirically motivate some form of epiphenomenalism, I nevertheless appreciate the fact that in light of the research on apparent mental causation, it is an open possibility that one day soon we may have to radically alter how we view human cognition and agency.

\section{Taking Stock}

My primary goal in this paper was to explore the unique problems and issues that arise when trying to rectify our traditional views about human agency and responsibility with the gathering data from the sciences of the mind. Fully plumbing the depths of these threats is a task for another day. For present purposes, I simply wanted to sketch the boundaries of the threats that I believe are already under foot and to show that they are independent of the issues that have traditionally been the focus of the free will debate. In this respect, I disagree with researchers who do not think advancements in psychology pose any new threats to free will above and beyond antecedently existing threats such as determinism, mechanism, reductionism, and the like (see, e.g., Roskies 2006). On my view, the new picture of human agency (or lack thereof) that is being pieced together by psychologists has the potential to radically transform the way we view ourselves both in relation to one another and to the world around us. Moreover, I believe that to the extent that these developments turn out to undermine our traditional views about free will, philosophers and psychologists ought to take an active roll in disabusing the public of their mistaken views on this front. By my lights, if our beliefs are inconsistent with the best available scientific data, these beliefs ought to be discarded just like the myriad other views that litter the ideological dustbins of human history. 
In this respect, I break with philosophers such as Smilansky and Nichols who both point to the alleged benefits of believing in libertarian free will and moral desert as grounds for leaving these beliefs in place. Whereas Smilansky suggests that we ought to keep quiet about the non-existence of free will (2000; 2002)—since our illusory beliefs on this front undergird our community of moral responsibility—Nichols similarly suggests that to the extent that nihilism about free will threatens to undermine social cooperation, we should either "relinquish or ignore" incompatibilism even if we otherwise find it to be intuitive (forthcoming). In this sense, both philosophers may accurately be identified with what Nichols calls a "counter-revolutionary agenda." On each of their respective views, the potential costs of a revolution about free will and responsibility outweigh whatever benefits we might derive from it.

I, on the other hand, would prefer to throw my lot with the nihilists and revolutionaries in the event that the potential threat of shrinking agency discussed in this paper is further bourn out by future research. At the end of the day, I advocate what might helpfully be called free will disillusinonism-i.e., the view that to the extent that folk intuitions and beliefs about the nature of human cognition and moral responsibility are mistaken, philosophers and psychologists ought to do their part to educate the public-especially when their mistaken beliefs arguably fuel a number of unhealthy emotions and attitudes such as revenge, hatred, intolerance, lack of empathy, etc. By my lights, humanity must get beyond this maladaptive suite of emotions if we are to survive. To the extent that future developments in the sciences of the mind can bring us one step closer to that goal—by giving us a newfound appreciation for the limits of human cognition and agency—I welcome them with open arms. 
Of course, not everyone will be so sanguine in the face of the potential death of free will. Indeed, they will likely share the worry captured by the following remarks from Wegner:

Many of the most strident arguments for free will hinge on the idea that a scientific understanding of human behavior could potentially ruin everything. The magic will be undone, the glorious human spirit will be cheapened, demystified, and rendered grotesque. We will uncover the trolls operating the machinery in the dungeon, and we will never again be able to appreciate the sparkling radiance of the Magic Kingdom of the self. Or, more realistically, we will uncover the genetic codes that produce neural structures that allow incoming sensations by social and situational factors to contribute to the cognitive computations that incline our motor output processes to lead us to behave-and then we lose the magic. (Wegner 2008: 235)

Wegner believes that this worry is overstated. On his view, the illusion of self-much like an optical illusion—will survive the onslaught at the hands of psychologists. As he says, "the magic is here to stay" (Wegner 2008: 243). Unlike Wegner, however, I have no time for magical powers and fairy tale endings—especially when they often do more harm than good. Indeed, not only do I think that developments in psychology will radically alter our conception of human agency, but I also happen to think that these potential changes represent a step in the right direction. As such, I am a disillusionist about free will and responsibility both descriptively and normatively. Figuring out which of us is right about the proper fate of free will is a thorny issue that will require philosophers and psychologists to continue to reach across disciplinary boundaries. But that, too, is a story for another day. ${ }^{16}$

\footnotetext{
${ }^{16}$ I would first like to thank the students in my seminar on free will and science at Dickinson College for their helpful feedback on the ideas contained in this paper. It was a pleasure to explore these issues with such eager minds. I also owe a special thanks to Eddy Nahmias - whose approach to the free will debate has had a formative effect on my own. So, even though we may disagree concerning the fate of free will, we nevertheless agree when it comes to the future direction the debate ought to take.
} 


\section{References}

Ayer, A.J. 1982. Freedom and Necessity. In G. Watson [Ed.] Free will. New York: Oxford University Press, 15-23.

Bargh, J. 1997. The automaticity of everyday life. In R.S. Wyer \& T.K. Srull [Eds.] Advances in social cognition (Vol. 10, pp. 1-61). Mahwah, NJ: Erlbaum. .2008. Free will is unnatural. In J. Baer, J. Kaufman, \& R. Baumeister, [Eds.] Are we free? Psychology and free will. New York: Oxford University Press,128-154.

Bargh, J.A., \& Chartrand, T.L. 1999. The unbearable automaticity of being. American Psychologist, 57 (7), 462-479.

Baumeister, R. 2008. Free will, consciousness, and cultural animals. In J. Baer, J. Kaufman, and R. Baumeister, (Eds.) Are we free? Psychology and free will. New York: Oxford University Press, 65-85.

Bayne, T. 2006. Phenomenology and the feeling of doing. In S. Pockett, W. Banks, \& S. Gallagher, [Eds.] Does consciousness cause behavior? An investigation of the nature of volition. Cambridge, MA: MIT Press, 169-186.

Bering, J. M., McLeod, K., \& Shackelford, T. K. 2005. Reasoning about dead agents reveals possible adaptive trends. Human Nature, 16, 360-381.

Berofsky, B. 2002. Ifs, cans, and free will: The issues. In R. Kane [Ed.] The Oxford handbook of free will. New York: Oxford University Press. 181-201.

Brown, J.W. 1989. The nature of voluntary action. Brain and Cognition, 10, 105-20.

Chisholm, R. 1982. “Human Freedom and the Self,” in Watson (1982b), 24-35.

Clarke, R. 1996. Agent causation and event causation in the production of free action. Philosophical Topics 24 (Fall), 19-48. . 2003. Libertarian accounts of free will. Oxford: Oxford University Press.

Claxton, G. 1999. Whodunnit? Unpicking the "seems" of free will. Journal of Consciousness Studies, 6, 99-113.

Darley, J. M., and Batson, C. D. 1973. From Jerusalem to Jericho: A study of situational and dispositional variables in helping behavior. Journal of Personality and Social Psychology 27: 100-108.

Dennett, D. 2008. Some observations on the psychology of thinking about free will. In J. Baer, J. Kaufman, and R. Baumeister, (Eds.) Are we free? Psychology and free will. New York: Oxford University Press, 248-259.

Double, Richard 1991. The non-reality of free will. New York: Oxford University Press.

Doris, J. M. 1998. "Persons, Situations, and Virtue Ethics.” Noûs 32: 504-530. . 2002. Lack of Character: Personality and Moral Behavior. New York: Cambridge University Press.

Ekstrom, L. 2000. Free will: A philosophical study. Boulder, CO: Westview Press.

Fischer, J.M. 1994. The metaphysics of free will. Oxford: Blackwell Publishers. . 2007. Compatibilism. In J. Fischer, R. Kane, D. Pereboom, \& M. Vargas [Eds.] Four views on free will. Oxford: Blackwell Publishing, 44-84.

Fischer, J., Kane, R., Pereboom, D., \& Vargas, M. [Eds.]. 2007. Four views on free will. Oxford: Blackwell Publishing.

Fischer, J.M., \& Ravizza, M. 1998. Responsibility and control: An essay on moral responsibility. Cambridge: Cambridge University Press. 
Frankfurt, H. 1988. The importance of what we care about. Cambridge: Cambridge University Press.

Gallagher, S. 2006. Where's the action? Epiphenomenalism and the problem of free will. In S. Pockett, W. Banks, \& S. Gallagher, [Eds.] Does consciousness cause behavior? An investigation of the nature of volition. Cambridge, MA: MIT Press, 109-124.

Haji, I. 2002. Compatibilist views of freedom and responsibility. In R. Kane [Ed.] The Oxford handbook of free will. New York: Oxford University Press, 202-228.

Harman, G. 1999. Moral philosophy meets social psychology: Virtue ethics and the fundamental attribution error. Proceedings of the Aristotelian Society 99: 315331.

. 2000. The non-existence of character traits. Proceedings of the Aristotelian Society 100: 223-226.

Hertel, G., \& Kerr, N.L., 2000. Priming in-group favoritism: The impact of normative scripts in the minimal group paradigm. Journal of Experimental Social Psychology, 37(4), 316-324.

Honderich, T. 1988. A theory of determinism. Oxford: Oxford University Press.

Isen, A. M. \& Levin, P. F. 1972. Effect of feeling good on helping: Cookies and kindness. Journal of Personality and Social Psychology 21, 384-388.

Kamtekar, R. 2004. Situationism and virtue ethics on the content of our character. Ethics 114, 458-91.

Kane, R. 1996. The significance of free will. New York: Oxford University Press. (ed.). 2002. The Oxford handbook of free will. Oxford and New York: Oxford University Press.

Kihlstrom, J.F., 2008. The automaticity juggernaut—or, are we automatons after all? In Baer, J., Kaufman, J., and Baumeister, R. (eds.) Are We Free? Psychology and Free Will. New York: Oxford University Press, 155-180.

Latane, B. \& Darley, J. 1970. The unresponsive bystander: Why doesn't he help? New York: Appleton-Century Crofts.

Libet, B. 1985. Unconscious cerebral initiative and the role of conscious will in voluntary action. Behavioral and Brain Sciences 8: 529-566. . 1999. Do we have free will? Journal of Consciousness Studies, 6 (8-9), 4757. . 2001. Consciousness, free action, and the brain. Journal of Consciousness Studies 8, 59-65. . 2004. Mind time. Cambridge: Harvard University Press.

Libet, B., Gleason, C., Wright, E., \& Pearl, D. 1983. Time of unconscious intention to act in relation to onset of cerebral activity (readiness potential). Brain 106, 623-42.

Logan, G.D. 1997. The automaticity of academic life: Unconscious applications of an implicit theory. In R.S. Wyer \& T.K. Srull [Eds.] Advances in social cognition. Mahwah, NJ: Erlbaum, 157-179.

Mathews, K. E. \& Cannon, L. K. 1975. Environmental noise level as a determinant of helping behavior. Journal of Personality and Social Psychology 32, 571-577.

Mele, A. 2001. Autonomous agents: From self-control to autonomy. New York: Oxford University Press. .2004. The illusion of conscious will and the causation of intentional action. 
Philosophical Topics 32, 193-213.

. 2006. Free will and luck. New York: Oxford University Press.

. 2008a. Recent work on free will and science. American Philosophical Quarterly

45(2): 107-130.

. 2008b. Psychology and free will: A commentary. In J. Baer, J. Kaufman, \& R. Baumeister [Eds.] Are we free? Psychology and free will. New York: Oxford University Press, 325-46.

Michotte, A. 1963. The perception of causality (T.R. Miles \& E. Miles, Trans.). New York: Basic Books

Milgram, S. 1974. Obedience to authority. New York: Harper and Row.

Miller, C. 2003. Social psychology and virtue ethics. The Journal of Ethics 7, 365-92.

Nadelhoffer, T., \& Feltz, A. 2007. Folk intuitions, slippery slopes, and necessary fictions: An essay on Smilansky's free will illusionism. Midwest Studies in Philosophy 13(1), 202-213.

Nahmias, E. 2002. When consciousness matters: A critical review of Daniel Wegner's The illusion of conscious will. Philosophical Psychology 15(4), 527-541.

. 2006. Folk fears about freedom and responsibility: Determinism vs. reductionism. Journal of Cognition and Culture 6(1-2), 215-237. . Forthcoming. The psychology of free will. In J. Prinz [ed.] The Oxford Handbook on the Philosophy of Psychology. New York: Oxford University Press.

Nahmias, E., Morris, S., Nadelhoffer, T., \& Turner, J. 2005. Surveying free will: Folk intuitions about free will and moral responsibility. Philosophical Psychology 18(5), 561-584.

. 2006. Is incompatibilism intuitive? Philosophy and Phenomenological Research, 73, 28-53.

Nichols, S. Forthcoming. After incompatibilism: A naturalistic defense of the reactive attitudes. Philosophical Perspectives.

Nichols, S., \& Knobe, J. 2007. Moral responsibility and determinism: The Cognitive science of folk intuition. Nous, 41, 663-685.

Nisbett, R., \& Wilson, T. 1977. Telling more than we can know: Verbal reports on mental processes. Psychological Review, 84, 231-259.

O'Connor, T. 1993. Indeterminism and free agency: Three recent views. Philosophy and Phenomenological Research, 53, 499-526. . 2000. Persons and causes: The metaphysics of free will. New York: Oxford University Press.

Ohbi, S.S., \& Haggard, P. 2004. Free will and free won’t. American Scientist, 92, 35865.

Overbye, D. 2007. Free will: Now you have it, now you don't. The New York Times. January, $2^{\text {nd }}$.

Pacherie, E. 2006. Toward a dynamic theory of intentions. In S. Pockett, W. Banks, \& S. Gallagher, [Eds.] Does consciousness cause behavior? An investigation of the nature of volition. Cambridge, MA: MIT Press, 146-168.

Pashler, H.E. 1998. The psychology of attention. Cambridge, MA: The MIT Press.

Pereboom, D. 2001. Living without free will. Cambridge, UK: Cambridge University Press.

Pockett, S., Banks, W., and Gallagher, S. 2006. Does consciousness cause behavior? An 
investigation of the nature of volition. Cambridge, MA: MIT Press.

Roskies, A. 2006. Neuroscientific challenges to free will and responsibility. Trends in Cognitive Science, Vol. 10 No. 9, 419-423.

Ross, P. 2006. Empirical constraints on the problem of free will. In S. Pockett, W. Banks, \& S. Gallagher, [Eds.] Does consciousness cause behavior? An investigation of the nature of volition. Cambridge, MA: MIT Press, 105-144.

Russell, P. 2002. Pessimists, pollyannas, and the new compatibilism. In R. Kane [Ed.] The Oxford handbook of free will. New York: Oxford University Press, 229-256.

Sabini, J. \& Silver, M. 2005. Lack of character? Situationism critiqued. Ethics 115, 535-562.

Shakespeare, W. 1610/2005. King Lear. In S. Wells, G. Taylor, J. Jowett, \& W. Montgomery [Eds.] The Oxford Shakespeare: The complete works $\left(2^{\text {nd }}\right.$ Ed. $)$. New York: Oxford University Press, 1153-1184.

Smilansky, S. 2000. Free Will and Illusion. New York: Oxford University Press. . 2002. Free will, fundamental dualism, and the centrality of illusion. In R. Kane [Ed.] The Oxford handbook of free will. New York: Oxford University Press, 489505.

Solomon, R. 2003. Victims of circumstances? A defense of virtue ethics in business. Business Ethics Quarterly, 13, 43-62.

Sommers, T. 2007. The objective attitude. The Philosophical Quarterly, 57, 321342.

Soon, C.S., Brass, M., Heinze, H.J., \& Haynes, J.D. 2008. Unconscious determinants of free decisions in the human brain. Nature Neuroscience, 11, 543-545.

Spence, S.A. 1996. Free will in the light of neuropsychiatry. Philosophy, Psychiatry, and Psychology, 3, 75-90.

Stace, W. 1960. Religion and the modern mind. Philadelphia: Keystone Books.

Strawson, G. 1986. Freedom and Belief. Oxford: Clarendon Press.

Thompson S.C., Armstrong,W., \& Thomas, C. 1998. Illusions of control, underestimations, and accuracy: A control heuristic explanation. Psychological Bulletin, 123, 143-61.

van Inwagen, P. 1983. An Essay on free will. Oxford: Oxford University Press.

Vargas, M. 2005. The revisionist's guide to responsibility. Philosophical Studies, 125(3), 399-429.

2007. Revisionism. In J. Fischer, R. Kane, D. Pereboom, \& M. Vargas [Eds.]

Four views on free will. Oxford: Blackwell Publishing, 126-165.

Walter, H. 2001. Neurophilosophy of free will: From libertarianism illusions to a concept of natural autonomy. Cambridge, MA: MIT Press.

Watson, G. [Ed.] 1982. Free will. New York: Oxford University Press. . 2004. Agency and answerability. New York: Oxford University Press.

Wegner, D. 2003. The illusion of conscious will. Cambridge: MIT Press. . 2008. Self is magic. In J. Baer, J. Kaufman, \& R. Baumeister [Eds.] Are we free? Psychology and free will. New York: Oxford University Press, 226-247.

Woolfolk, R. L, Doris, J. M., \& Darley, J. M. 2006. Identification, situational constraint, and social cognition: Studies in the attribution of moral responsibility. Cognition $100,283-301$.

Zhu, J. 2003. Reclaiming volition. Consciousness and Cognition, vol. 10, 61-77. 
